\title{
Between myth and mathematics: the vicissitudes of Archimedes and his work
}

\author{
Pier Daniele Napolitani
}

Published online: 16 August 2013

(C) Centro P.RI.ST.EM, Università Commerciale Luigi Bocconi 2013

\begin{abstract}
This paper traces the complex history of both the work and the myth of Archimedes from third century B. C. Syracuse to its fading with the fall of the ancient world; through the Arab world; to its resurrection in the Byzantine scriptoria of the ninth century A.D., and to its reappearance in the courts and libraries of the Italian Renaissance. It will be from the encounters and frictions between these cultureshumanistic and 'technical' - that the rediscovery of Archimedes will be transformed in the first phase of modern mathematics and science.
\end{abstract}

Keywords Archimedes - Archimedean tradition . Leo the mathematician - William of Moerbeke . Gerard of Cremona $\cdot$ Jacobus de Sancto Cassiano Cremonensis $\cdot$ Regiomontanus $\cdot$ Niccolò Tartaglia . Francesco Maurolico - Federico Commandino . Johan Heiberg

\section{Tradition and traditio}

Tradition, as it is currently understood, means the transmission of the cultural heritage of past generations; it is not without various shades of meaning, such as 'folkloristic tradition' or 'family traditions'). Tradition can even be bizarre and odd: kissing under the mistletoe, eating Christmas pudding, pulling someone's ears on his or her birthday. The concept of tradition in philology is more austere: traditio is the process by which the work of an

P. D. Napolitani $(\bowtie)$

Department of Mathematics, University of Pisa,

Largo Bruno Pontecorvo 5, 56127 Pisa, Italy

e-mail: napolita@dm.unipi.it author has come down to us, that which the text translates to us, which is incarnated over and over again in its witnesses, that is, the manuscripts and print editions in which it is passed down.

Those who wish to approach the person and the work of Archimedes soon discover that, in this case, these two meanings are inseparable. On one hand there is a myth that began growing in Antiquity, and which in the Latin West, beginning with the Renaissance of the 13th century, became an operative myth: that is, it leads to searching for texts, translating them, and working on them in hopes of discovering those secrets that made Archimedes into a myth. 'Tradition' thus results in the construction of a complex textual traditio, one capable of orienting research for centuries and centuries and of shaping in its own image the conception and birth of the new Galilean science and the first steps of a completely new mathematics.

In what follows we will discuss this complex history: from third century B.C. Syracuse to its fading with the fall of the ancient world; to Baghdad and the other centres of the Arab world; to its resurrection in the Byzantine scriptoria of the ninth century A.D., and to its reappearance in the courts and libraries of the Italian Renaissance with its engineers and artists. It will be from the encounters and frictions between these cultures-humanistic and 'technical'-that the rediscovery of Archimedes will be transformed in the first phase of modern mathematics and science.

\section{A misunderstood genius?}

In the Classical world, the work of Archimedes appears not to have enjoyed the fame that today we might expect it to have. The scant success is due to many factors, including Archimedes having been on the periphery of the important 
Greek cultural centres, and the intrinsic difficulties of his style. Further, his work concerns topics of geometry of measure and of mechanics, and it appears that instead the mainstream of Hellenistic mathematics was concentrated on the geometry of curves. It appears that Archimedes himself was aware of these difficulties, as can be sensed from his tone-often disconsolate-with which he sends his work to Alexandria.

The scant consideration given his writings runs counter to the fame that he enjoys as a person. In her recent book, Archimedes and the Roman Imagination [8], Mary Jaeger collects all the stories traditionally related to this mathematician: stories passed down by an array of writers such as Polybius, Cicero, Titus Livius and Plutarch, to name only the best known. As we mentioned, it would be these stories that constituted the fundamental ingredients for the myth of Archimedes:

- The brilliant engineer and inventor: the sailing of the gigantic ship Syracusia; the legend of the crown; the inventions attributed to him, from the marvellous planetarium to war machines;

- The defender of his country, true soul of the resistance against the barbarous Romans: the manus ferrea that grasped the Roman ships and hurled them into the water; the burning mirrors that set the triremes aflame, and so forth;

- The 'captive of the muses' or the 'absentminded genius' described by Plutarch: the one who ran naked through the streets of Syracuse crying 'Eureka! Eureka';

- Wisdom and power: his relations with the royal house of Syracuse; the conqueror Marcellus who wanted him taken to Rome as part of the spoils of war (or rather, as Lorenzo Braccesi maintains, wanted him dead).

Finally, the story-obscure-of his death [2]: was his throat cut in error by a Roman soldier during the siege of Syracuse, while he was absorbed in his geometry, or was he ordered to be killed as the leader and guide of the proCarthage party?

With the decline of the ancient world, the fame of Archimedes also seems to have declined, and with regard to the traditio of his work, the difficulties already present during the age of greatest development of Hellenistic mathematics, must be added the general decadence of the mathematical sciences during the Imperial age. It is thus easy to understand why, in the sixth century, the commentator Eutocius of Ascalon gave signs of knowing only three of his works: On the Sphere and Cylinder, Measurement of the Circle, and Plane Equilibria. It is certain that Eutocius, in spite of taking pains to search for ancient texts and manuscripts, did not know the Quadrature of the Parabola, and almost certain that did he not know $O n$
Spirals. In short, at the end of the Classical world, Archimedes' most profound works appear to have been completely forgotten-On Spirals, On Conoids and Spheroids, Method - the very ones that contained ideas and intuitions which, read with the fresh eyes and new points of view of the sixteenth and seventeenth centuries, were destined to become one of the roots of modern mathematics.

\section{Archimedes in the middle ages}

On the eve of the Arab conquests, the study of Archimedes in the Byzantine world thus had to be limited to the three works just mentioned, On the Sphere and Cylinder, Measurement of the Circle, and Plane Equilibria. It was perhaps for this reason that essentially in the Arab world only these works were known, even though Arab mathematicians developed their own 'neo-Archimedean' mathematics. Beginning in the ninth century with the three brothers Muhammad, Ahmad and Al-Hasan (known as the Banū Mūsā) and Thābit ibn Qurra, until the eleventh century with the great Alhazen, Arab mathematicians achieved very elegant proofs and results that sometimes went beyond those obtained by Archimedes himself. Be that as it may, these research works remained a kind of appendix to the Greek results without arriving at breaking the Greek paradigm, centred on 'concrete' mathematical objects defined by a constructive procedure. The novelty of these so-called Arabic 'infinitesimal mathematics' are limited to a few new solids (for example, the parabolic 'lemon', obtained by rotating a segment of parabola about its base) or the determination of the centre of gravity of paraboloids of revolution.

The list of works either by Archimedes himself or inspired by Archimedes known in the Latin Middle Ages is thus rather a brief one. This first penetration of Archimedes into the West after the end of the ancient world is strictly related to the relationship to the Islamic world, which is collocated in what Haskins has called the 'Renaissance of the twelfth century' [5]. The leading figure of this spread of ideas-which brought Measurement of the Circle back into circulation in the Latin world-was Gerard of Cremona (1147-1187), who translated from Arab something like ninety scientific works. Along with De mensura circuli, Gerard had also translated an original work of the Banū Mūsā, which retraced the results of the On the Sphere and Cylinder, a work which was widely circulated in the West under the title Verba filiorum.

Along with the Verba filiorum, we might also mention the Liber de curvis superficiebus from the beginning of the thirteenth century, which would continue to exert a certain influence at least until the end of the first half of the 
Cinquecento: Francesco Maurolico was inspired by it to attempt, in the 1520s, a reconstruction of Archimedes' On the Sphere and Cylinder. We might also cite the Liber Archimenedis de ponderibus (a pseudo-Archimedean treatise dating to the twelfth-thirteenth century), which dealt with what today we might call the determination of the specific weight of a mixture. This text enjoyed very good fortune until the end of the sixteenth century and even beyond: it probably influenced the young Galileo and was printed in an Italian translation again in 1644, together with the first printed edition of Galileo's Bilancetta [3].

Above all, the principal driver of this first rebirth of mathematics was the work of Leonardo of Pisa: his Liber abaci and Practica geometriae were the primary means of transmission of Greek mathematical culture, mediated by the Arab-Latin tradition, in that intermediate cultural stratus (as Carlo Maccagni put it) that was born and developed precisely during the twelfth to fourteenth centuries with the new wealth and power enjoyed by the Latin West. While it is true that in the world of abacus schools the structure of proofs of Greek geometry progressively lost its hold to the extent that it finally almost evaporated completely, it is also true that it was through the abacus schools that numerical literacy on a mass scale was achieved. It would also be thanks to this phenomenon thatwhen in the Cinquecento all of Archimedes' texts began to circulate more widely-the Greek paradigm would be reappropriated on a decidedly new basis.

\section{Archimedes between Byzantium and Viterbo}

\section{$4.1 \mathrm{~A} \mathfrak{B} \mathrm{C}$}

Until the thirteenth century, the Latin West thus knew very little of Archimedes, and it appears that his very name was almost forgotten: the sources distort it into forms derived from the Arabic such as 'Ersemides' or 'Arsamithes'. Likewise his myth seems to have dimmed in the fog of the times: in medieval chronicles the figure of Archimedes barely appears. His work seems to have been almost completely forgotten. Indeed, the quadrature of the circle is often cited because it does not conform to Aristotle's placita: 'He left a work on the quadrature of the circle, of which Aristotle says it is knowable but is not known'.

Things went differently in the Byzantine world, which towards the middle of the ninth century experienced a kind of Renaissance, connected to the figure of Leo the Mathematician, the reformer of studies in Constantinople. Thanks to his impulse, between the ninth and tenth centuries at least three manuscripts were compiled containing works of Archimedes. Two of these-the so-called codices $\mathrm{A}$ and $\mathfrak{B}$-would later arrive to the West, making it possible to know the lion's share of the corpus of Archimedes' works known today.

Codices $\mathrm{A}$ and $\mathfrak{B}$ are the that William of Moerbeke came upon. In 1269 he translated into Latin all the works contained there, except for the Arenarius (Sand Reckoner) and Eutocius's commentary on the Measurement of the Circle. The autograph manuscript of the translation, discovered in 1881 by Valentin Rose, is now conserved in the Vatican Library (ms. Ottobonianus latinus 1850). However, codex $\mathfrak{B}$ was lost not long after 1311 and with it the Greek text of the two books On Floating Bodies, not found in codex A.

As for the third Byzantine codex, denominated C, it was destined to become a 'palimpsest': as early as the thirteenth century, its folia were washed, erasing the texts of Archimedes in order to recycle the parchment and compile a new codex to be used as a prayer book for exorcisms. Only in 1906 was Johan Heiberg able to read the inferior scriptio, that is, the faint early text beneath the writing of the next codex. Thus was recuperated the Greek text of On Floating Bodies, along with a second, likewise previously unknown text that Heiberg named The Method of Mechanical Theorems. ${ }^{1}$ Lost once again in the chaos of the Turkish revolution, codex $\mathrm{C}$ turned up again in 1998 at an auction in New York. Today it has been restored and studied with the aid of digital photography. ${ }^{2}$

\subsection{Archimedes in Viterbo}

A great translator of philosophical works, Moerbeke worked for several years in the papal court in Viterbo. In the thirteenth century, this city in Lazio was a first-rate centre for culture and science that attracted figures such as

\footnotetext{
1 The title contains the term ephodos, not methodos: these two terms do not mean exactly the same thing, the first being less emphatic and more generic than the second. Further, in the text neither term ever appears. Instead consider the term tropos, which might be translated as 'way' or 'approach'. Nevertheless, Heiberg chose to translate the title with Method, convinced as he was that "die neue Methode des Archimedes ist tatsächlich mit der Integralrechnung identisch", that is, that the techniques set forth by Archimedes in the manuscript he had discovered were identical with those of integral calculus (see [7]). On the meaning of the techniques used by Archimedes in the Method, see [12].

${ }^{2}$ For the fascinating story of codex $\mathrm{C}$ we refer the reader to the book by [9], among those directly involved with the recovery of the palimpsest. We wish in any case to warn the reader to be on guard against Netz's enthusiasm for the discovery of 'mathematical secrets' and disconcerting prefigurations of twentieth-century mathematics in the text of the palimpsest. His convictions of this surpass even those of Heiberg. A detailed history of the codex and description of its contents can be found in the recent two-volume The Archimedes Palimpsest [10]; the second volumen contains the transcription of all the texts of the manuscript, which also contains fragments of two previously unknown orations by Hypereides, as well as a commentary on Aristotles's Categories, also previously unknown.
} 
Campanus of Novara (to whom we owe the edition of Euclid that was a point of reference through the mid-sixteenth century) and John Peckham, whose Perspectiva communis was a compendium of the great works on optics by the Polish scientist Witelo, friend and fellow Dominican of William [11]. It was probably thanks to the stimulation of a milieu so attentive to mathematics that led Moerbeke to translate Archimedes, a translation that assumed an inestimable importance, for two reasons. In the first place his style, extremely literal and faithful to the Greek text, make it possible to make up for the loss of codex $\mathfrak{B}$. The second reason is that the Greek text of On Floating Bodies was not contained in codex A (which was widely circulated in the Renaissance). With the loss of $\mathfrak{B}$, which presumably occurred shortly after 1311, the year when it was last catalogued, Moerbeke's Latin translation was destined to remain the only witness of the text of Floating Bodies until the beginning of the twentieth century.

Thus we see that by the end of 1269 practically the entire body of the work of Archimedes, with the exception of Arenarius and Method, was available in Latin. We might then expect that Archimedes was amply read and studied during the middle ages. This was not the case. The court in Viterbo enjoyed only a short season: shortly after would come the crisis that was to upset all aspects of society in the fourteenth century. The times were little propitious for studies and that certainly contributed to the fact that William's translation was doomed to be ignored for a while. Moreover, Archimedean mathematics is difficult and can be understood only by means of the complete mastery of the entire corpus of Greek geometry: the Euclidean theory of proportions, Book XIII of the Elements, knowledge of the theory of conic sections. All of this was still lacking or had not been sufficiently assimilated.

However, the fourteenth century, and above all the Quattrocento, were the centuries in which the culture of the abacus would undergo an enormous development, thus generating widespread mathematical proficiency. And in those same decades, the flowering of humanism would open new perspectives and new horizons.

\section{The Quattrocento}

\subsection{The Humanistic rediscovery and Jacobus de Sancto Cassiano Cremonensis}

From the Byzantine world, by now on the verge of its definitive collapse, there came a flow of treasures of Classical culture into the West, together with, through Euripides and Plato, works of the sciences and mathematics. Thus it happened that, at the beginning of the 1430 , news spread quickly among the humanists engaged in this gigantic activity of recovery that a Greek codex of Archimedes was in the possession of Rinuccio da Castiglione. This caused a huge sensation, and letters flew between the capitals of humanist Italy: much more needed to be known, and many were desirous of obtaining a copy of the precious original. Then, suddenly, there was silence, perhaps because the news turned out to be groundless, perhaps because the codex, in spite of all efforts to preserve it, had been lost.

It is worthwhile underlining one aspect of this first kindling of humanistic interest in the work of Archimedes: Rinuccio's mysterious manuscript was supposed to bear the title De instrumentis bellicis et aquaticis, and thus was a work of mechanics or military engineering. In the same way, at the end of the century, when Poliziano discovered codex $A$ in the Venetian library of Giorgio Valla (see "Appendix"), he seemed more interested in Archimedes as an inventor of machines and instruments of war than as a scholar of a geometry that was difficult and abstract. It is no coincidence that, more than in the works of Archimedes, Poliziano showed himself to be interested in the second section of the codex, which contained a work by Heron regarding mechanicus, as shown by several letters from 1491.

This does not indicate a 'humanistic' disdain for mathematics: such disdain is - unfortunately-a characteristic of times much closer to our own. The truth is that, beginning at least with Petrarch, Italian humanism rediscovered the legend of Archimedes. From the accounts of the classical writers who reappeared in the bookshelves and the writing desks of the Humanists emerged a portrait of a strong defender of his country, the inventor of marvellous devices. This legend soon infected the domains whose practitioners were educated above all in the culture of the abacus: engineers and painters, architects and military men. This aspect of the Archimedean tradition would soon assume a crucial importance.

In 1447 the humanist Tommaso Parentucelli became Pope Nicholas V and created the Vatican Library. He commissioned the translation into Latin of Greek texts, including works of science. It was at his behest that George of Trebizond translated Ptolemy's Almagest into Latin, and Teodoro Gaza translated the scientific works of Aristotle. It was in his court that interest in Archimedes was rekindled. This is context in which is collocated the new Latin version of the Archimedean corpus, containing all the works of Archimedes found in codex A together with the commentaries by Eutocius. The author of the translation was Jacobus de Sancto Cassiano. A humanist educated at the school of Vittorino da Feltre, Jacobus had studied at the University of Pavia and in 1446 he had succeeded his teacher as director of the 'Giocosa', the school founded by the marquises of Mantua. In 1451 he 
transferred to Rome, where the following year he was charged with the translation of the mathematical works. Among other things, he was assigned the task of revising Trebizond's Almagest and his criticisms of his colleague aroused a furious polemic. Recent studies have made it possible to identify ms. Nouv. Acq. Lat. 1538 conserved in the Bibliothèque nationale de France as the autograph manuscript, and above all to prove that Jacobus had access to a Greek manuscript that was different from codex A, lost today [4].

\subsection{Bessarion, Regiomontanus and the Basel editio princeps}

Jacobus died around 1454, and silence appears to shroud his reputation and his translation: a silence made more mysterious when we take into account that he was connected to many humanists of the day. It thickens further when we reflect that none of the manuscripts of his translation bear his name. In fact, in one of the them (the autograph manuscript Nouv. Acq. Lat. 1538 just mentioned), a note in a later hand attributes the translation to a fellow townsman of Piero della Francesco, Francesco Cereo da Borgo San Sepolcro (d. 1468), of whom we shall speak shortly.

The Archimedes Latinus had, however, attracted a great deal of attention in some humanistic circles, especially those connected to Cardinal Bessarion, to whom credit is owed for bringing together Archimedes and Johannes Müller von Königsberg, better known as Regiomontanus (1436-1476), perhaps the greatest mathematician of the Quattrocento. Becoming part of Bessarion's retinue in Vienna, he was able to learn Greek and make good use of the codices that the cardinal had collected. In particular, he was able to consult a copy of Jacobus's translation as well as a copy of the Greek text of codex A, manuscripts that Bessarion possessed. Among other things, it is thanks to Regiomontanus that today we know the name of the author of the translation of Archimedes.

Almost certainly informed by Bessarion about the events that had occurred in the early 1450s and the vicissitudes of the translation, the young German mathematician clearly indicated Jacobus as the author of the translation. He wrote it in a kind of publishing catalogue printed in 1470. Intuiting the enormous potential of print, he in fact planned to undertake an edition of Archimedes in the context of a vast program of scientific publications intended to make widely known the treasures of Greek mathematics as well as his own personal discoveries. Death visited him prematurely in 1476, impeding him from carrying the project to completion. However, his labours over Archimedes were not in vain: in 1544 in Basel was published the Greek-Latin editio princeps declaredly based on the work that Regiomontanus had done to improve Jacobus's translation in several places.

Without exaggeration, it can be maintained that this event provided an impulse for the birth of modern science that was on a par with the publication of Copernicus's De revolutionibus orbium caelestium in 1543 . Thanks to the Basel printed edition, Archimedes was finally able to leave the shelves of erudite libraries and speak directly to natural philosophers, mathematicians and engineers. It the Basel Archimedes Latinus that the young Galileo knew and studied. This was the Archimedes that, between the end of the sixteenth century and the first decades of the seventeenth, inspired a radical change in the way mathematics was understood.

\subsection{Archimedes in the abacus tradition}

We mustn't think, however, that Archimedes' work was a source of interest in humanistic circles alone. To the contrary. Around 1458 Francesco Cereo-a relative of Piero della Francesca, apostolic notary and architect (he was the designer of the Palazzo Venezia in Rome)- had Jacobus's autograph copied in a splendid illuminated manuscript: once part of the famous library of the Dukes of Urbino, today it is conserved in the Vatican Library (ms. Urb. Lat. 261). Francesco himself drew the geometric figures, in collaboration with Piero, who, in his turn, transcribed a copy of Francesco's manuscript of Archimedes. In 2005 James [1] identified this copy, partly autograph, in the Biblioteca Riccardiana in Florence (ms. Ricc. Lat. 106).

The efforts of Piero and Francesco to correct the text are remarkable: in spite of the fact that Archimedean mathematics went beyond what they knew, they nevertheless succeeded at times in providing coherent figures where Jacobus had reproduced the erroneous diagrams that appeared in the Greek source he used. Further, Piero used Archimedes to obtain various, sometimes original, results that appear in his Libellus de quinque corporibus regularibus: noteworthy among these is that on the calculation of the volume and surface of a groin vault. To be sure, in reading the explanation that Piero gives for the Archimedean results in the Libellus, one is struck by how distant Piero's style is from that of the Greek geometer. For example, in calculating the volume of the groin vault, Piero appears to reason by analogy with how much he was able to understand from On Conoids and Spheroids, arriving at the correct result more through intuition than on the basis of a reasoning informed by deductive rigour.

Piero's attempts would soon be followed by those of Leonardo da Vinci and Luca Pacioli. Leonardo was active in searching for Archimedean codices, as shown by various 
of his notebooks, as he also attempted to achieve new results (for example, the centre of gravity of the pyramid); the same is true of Pacioli, who used Jacobus's Archimedes to enrich his Summa de arithmetica, geometria, proportioni et proportionalità (1494). The fact remains, however, that in the translation of Jacobus, the tradition of humanism and that of abacus culture are remarkable intertwined. While it is true that only a mathematician of the calibre of Regiomontanus was able to resolve at least in part some of the difficulties with which Archimedes text bristles, it is also true that Piero, Leonardo and Pacioli grappled with that same text to arrive at with results that are impressive.

\section{The Cinquecento}

\subsection{Tartaglia}

Within these technical and artistic milieus, interest in recovering ancient mathematical traditions continued to grow over the course of the Quattrocento and Cinquecento. At the same time, research in the field of algebra, an art which had been developed only in abacus circles, had matured. It would be a figure trained in precisely this culture, Niccolò Tartaglia (1499/1500-1557), who would attempt to follow both of these threads. In the $1530 \mathrm{~s}$, Tartaglia independently discovered Scipione del Ferro's rule for extracting the roots of cubic equations in function of the coefficients, and attempted to construct a geometric model for the trajectory of projectiles (Nuova scientia 1527).

Like Regiomontanus and Pacioli before him, Tartaglia was well aware of the crucial importance of the printing press for this new scientific culture, which sought to unite the 'new' ancient mathematics with the spirit of abacus mathematics. Thus in 1543, having come into possession of a partial copy of William of Moerbeke's translation, he published a compilation of Archimedean writings; shortly after he proposed applying the Archimedean theory of floating bodies to the recovery of sunken ships (La travagliata inventione 1551). Like Piero, the maestro d'abaco Targalia moved against a humanistic backdrop. It is true that his interlocutors were 'bombadiers' and technicians, but they also included figures such as Diego Hurtado de Mendoza (1503-1575), the ambassador of Holy Roman Emperor Charles V, with whom Tartaglia discussed mechanics and 'scientia de pesi'. Finally, in the General trattato di numeri e misure, which appeared posthumously in 1557, he goes back over the results of Archimedes relative to the sphere and cylinder, basing himself on William's translation. The mathematics of the technicians, artists and merchants finally encountered Archimedes, but there is still a long way to go.

\subsection{Archimedean mathematics: Maurolico and Commandino}

Already by 1528 a scholar from Messina, Francesco Maurolico (1494-1575), had planned a vast programme of restoration of the mathematical disciplines and to that end, not having at his disposal a copy of the texts of Archimedes, he put his hand to a kind of divination of Plane Equilibria, Measurement of the Circle and On the Sphere and Cylinder, based on the Arab-Latin tradition and on what he could glean from various sources.

The four books of De momentis aequalibus, in which Plane Equilibria is reconstructed, contain an original study of the centres of gravity of solids as well as an even more original model of equilibrium, in which an essential role is played by the concept of 'mechanical moment', intended as weight $\times$ distance. Archimedean mathematics is thus recovered and integrated into the context of the mathematical knowledge that developed over the course of the sixteenth century. Unfortunately, the majority of the work of Maurolico remained unpublished, even though his results and his approach circulated among the Jesuits.

If during the course of the Cinquecento Archimedean mathematics came to be imposed as the model to be followed in study and research, this is largely due to Federico Commandino (1509-1575) and his school. Around 1550 Commandino was invited by Cardinal Marcello Cervini to revise Moerbeke's translation of $\mathrm{On}$ Floating Bodies. In order to carry out this task, he devoted himself to an in-depth mathematical and philological studies of the works of Archimedes and the Conics of Apollonius. The fruits of these studies were rigorous Latin translations enriched by commentary: Archimedis Opera nonnulla (1558), De iis quae vehuntur in aqua libri duo (his revision of On Floating Bodies 1565), and the Latin version of Apollonius's Conics (1566). Maurolico did not succeed in publishing the results of his research, but those of Commandino enjoyed a widespread circulation. Moreover, he gathered about him a school of mathematicians and technicians that flourished at the turn of the seventeenth century. His work provided readers with a thread for taking back the culture of Greek mathematics: the Liber de centro gravitatis solidorum (1565) inaugurated a line of original research that was destined to arrive, with the mediation of Luca Valerio (1553-1618), to Bonaventura Cavalieri's invention of the theory of indivisibles. 


\subsection{Guidobaldo dal Monte and mechanics as science}

Among the pupils of Commandino was Guidobaldo dal Monte (1545-1607), scion of one of the most important noble families in the Duchy of Urbino, who dedicated himself to mathematics and mechanics, as well as civil and military architecture. He completed the work of his teacher by publishing, in 1588, an amply commented paraphrase of Plane Equilibria, in the preface to which he reiterated the importance of mechanics as a science and attempted to reconcile the Archimedean conception of centres of gravity with Aristotle's natural philosophy. Most importantly, however, Guidobaldo published the Mechanicorum liber (1577), in which the five simple machines were all reduced to the balance. The aim of the treatise was to elevate the status of mechanics from an 'art' to a 'science': a geometricised science, in which the Archimedean notion of centre of gravity assumed a central role. The book was quite successful and was translated into the vulgar in 1581 with the title Le mechaniche... nelle quali si contiene la vera dottrina di tutti gli istrumenti principali da mover pesi grandissimi con picciola forza (The mechanics... in which is contained the true doctrine of all the principal instruments that can move enormous weights with little force).

Guidobaldo, military architect, expert of mechanics and mathematics: like Archimedes himself. It is no coincidence that it was precisely with his Mechanics that the legend of Archimedes melded with the lessons that the Quattrocento and Cinquecento had learned from his works. And at the same time, Guidobaldo was mentor and friend to the young Galileo. By that time something radically new was just about to be born, but the seeds that led to this birth were found in the interweaving of Archimedean tradition and traditio, of myth and mathematics.

\section{Appendix: Codex A and the Heiberg Archimedis Opera Omnia}

Codex A lies at the root of the Basel editio princeps and thus at the later diffusion of Archimedes. In the course of the Quattrocento, it arrived in the hands of Giorgio Valla (1447-1500). A great collector of Greek manuscripts, above all of mathematics, he used them to compile a vast encyclopaedia, curiously named De expetendis et fugiendis rebus opus (On the things to seek and shun, Venice, 1501), which remained incomplete at his death and was published posthumously. Here for the first time appear some fragments of Eutocius's commentary on Archimedes, which would have a notable influence on the mathematical research of the Cinquecento. After much urging, Valla had allowed Poliziano to make a copy of Codex A for Lorenzo il Magnifico. This apograph, creating in imitation of the writing and mise en page of the antigraph, is today conserved in Florence in the Biblioteca Medicea Laurenziana (ms. Plut.28.4).

After Valla's death his library was acquired by Alberto III Pio of Carpi (1475-1531), and then inherited by his nephew, Cardinal Rodolfo Pio (1500-1564). The last notice of Codex A appears in the inventory of Rodolfo's possessions made when he died; after this, all traces are lost. Fortunately, in the course of the Cinquecento the ancient exemplar had been copied several times; these copies, along with the Palimpsest $\mathrm{C}$, form the basis of the critical edition of the Archimedean corpus edited by Heiberg. The first edition [6] was essentially based on the Laurentian Library codex as well as three other copies made directly from A; the second edition (1913-1915) took into account discoveries that had been made in the intervening 30 years, including the rediscovery in the Vatican Library of Moerbeke's translation and that of the Constantinople palimpsest. (Translated from the Italian by Kim Williams.)

\section{References}

1. Banker, J.R.: A Manuscript of the works of Archimedes in the hand of Piero della Francesca. Burlington Mag. 147(1224), 165169 (2005)

2. Braccesi, L.: L'assassinio di Archimede. Hesperìa 22, 161-166 (2008)

3. Clagett, M.: Archimedes in the middle ages, vol. 5, University of Wisconsin Press, Madison (1964-1984)

4. D’Alessandro, P., Napolitani, P.D.: Archimede latino. Les Belles Lettres, Paris (2012)

5. Haskins, C.H.: The Renaissance of the Twelfth Century. Harvard University Press, Cambridge (1955)

6. Heiberg, J.L.: Archimedis Opera Omnia cum Commentariis Eutocii. vol. 3, B. G. Teubner, Leipzig (1880-1881)

7. Heiberg, J.L.: Eine neue Archimedeshandschrift. Hermes 42 , 236-303 (1907)

8. Jaeger, M.: Archimedes and the Roman Imagination. The University of Michigan Press, Ann Arbor (2008)

9. Netz, R., Noel, W.: The Archimedes Codex: How a Medieval Prayer Book Is Revealing the True Genius of Antiquity's Greatest Scientist. Weidenfeld \& Nicholson, London (2007)

10. Netz, R., Noel, W., Tcherneska, N., Wilson, N.: The Archimedes Palimpsest. Cambridge University Press, Cambridge (2011)

11. Paravicini Bagliani, A.: Medicina e scienze della natura alla corte dei Papi nel Duecento. Centro italiano di studi sull'alto Medioevo, Spoleto (1991)

12. Saito, K., Napolitani, P.D.: Reading the Lost Folia of the Archimedean Palimpsest: the Last Proposition of the "Method". In: From Alexandria, Through Baghdad: Surveys and Studies in the Ancient Greek and Medieval Islamic Mathematical Sciences in Honor of J.L. Berggren, N. Sidoli and G. Van Brummelen (eds.). Springer, Berlin (2013) 


\section{Author Biography}

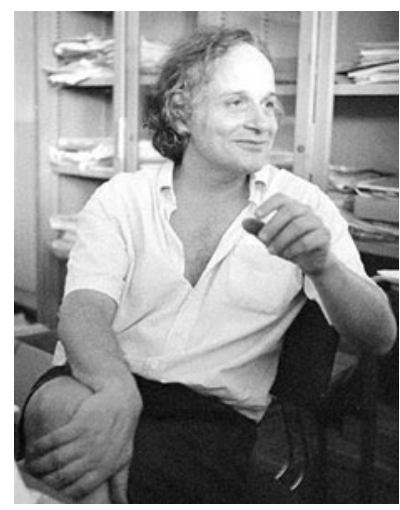

Pier Daniele Napolitani (b. Rome, 1951) is a historian of mathematics whose work concerns the first modern period: in particular, he has always been fascinated by the figure of Archimedes and the rediscovery of this work during the Renaissance. He has published various studies on Italian mathematician Luca Valerio; in collaboration with Ugo Baldini he edited the correspondence of Clavius (now available on the ECHO website: http://echo.mpiwg-berlin.mpg.de/ content/mpiwglib/clavius). He is president of the Italian National Edition of the mathematical works of Francesco Maurolico (www. maurolico.it), which aims to make all of the works of this great mathematician available for the first time. He had the good fortune and privilege of working with Paolo d'Alessandro on a study of Archimede latino (Les Belles Lettres, Paris, 2012), thus realising his dream of approaching the Archimedean tradition with the instruments and rigour of classical philology. 